\title{
Evaluasi Kesuksesan dan Keberterimaan Sistem Informasi Anggaran PT. PLN (PERSERO)
}

\author{
Andi Nurul Istiyana \\ Politeknik Negeri Ujung Pandang \\ andiistiyana@yahoo.co.id \\ (Diterima: 07-Mei-2020; dipublikasikan: 31-Juli-2020)
}

\begin{abstract}
The success of information systems is one thing that needs to be evaluated. Not only the success, but the acceptance of information systems by users also need to be considered. However, some of these studies do not pay attention to the nature of system use is mandatory or voluntary. The considerable implementation costs and expected results are a consideration of why this evaluation needs to be done. Data collection was done by distributing questionnaires to budget employees of PT PLN (PERSERO). In this research will be tested the success of information system by using DeLone and Mclean success model (1992), then add testing to system acceptance by using perception of usage and perception of ease of use from model of acceptance developed by Davis (1989). The use of compulsory systems is a consideration for combining the two models. The results show that the budget system is successfully applied to PLN but there are some obstacles and there is no effect of the usability of the perception and ease of use of perception on the system because the system is mandatory.
\end{abstract}

Keywords: Informationsuccess; System acceptance; Budgeting system, Mandatory

\begin{abstract}
Abstrak
Kesuksesan system informasi merupakan satu hal yang perlu untuk dievaluasi. Tidak hanya kesuksesan, namun keberterimaan sistem informasi oleh pengguna juga perlu untuk dipertimbangkan. Namun beberepa penelitian tidak mempertimbangkan penerapan sistem yang bersifat wajib atau sukarela. Biaya implementasi sistem yang cukup besar dan hasil yang diharapakn tercapai menjadi pertimbangan mengapa evaluasi terhadap sistem perlu dilakukan. Penelitian ini mencoba untuk melakukan evaluasi sistem dan keberterimaan pengguna terhadapa sistem informasi anggaran. Pengumpulan data dilakukan dengan penyebaran kuesioner kepada pegawai devisi anggaran PT PLN (PERSERO). Pada penelitian ini akan melakukan evaluasi atas sistem anggaran dengan menggembangkan model kesuksesan DeLone dan Mclean (1992), dikaitkan dengan kegunaan persepsi dan kemudahan penggunaan persepsi dari model keberterimaan yang dikembangkan oleh Davis (1989). Penggunaan sistem yang bersifat wajib menjadi pertimbangan untuk menggabungkan dua model tersebut. Hasilnya menunjukkan bahwa sistem anggaran sukses di terapkan pada PLN namun terdapat beberapa hambatan dan tidak terdapat pengaruh kegunaan persepsi dan kemudahan penggunaan persepsi pada sistem yang dikarena sistem tersebut bersifat wajib.
\end{abstract}

Kata Kunci: Kesuksesan sistem; Keberterimaan sistem; Sistem anggaran,mandatori 
Penerapan sistem informasi merupakan satu hal yang sangat penting dalam suatu perusahaan. Sistem informasi penting karena kemajuan teknologi dipandang sebagai jalan untuk mencapai competitive adventage.

Penggunaan sistem informasi juga dimaksudkan untuk mengatasi meningkatnya kebutuhan informasi yang akurat dan tepat waktu. Di satu sisi biaya implementasi sistem yang tinggi membutuhkan perencanaan dan pelaksanaan yang tepat.

Total pengeluaran perusahaan di berbagai belahan dunia untuk bidang teknologi informasi (TI) melebihi satu milyar dollar pertahun dan bertambah sebesar $10 \%$ di setiap tahun.

Pada saat yang sama sistem informasi hampir meliputi semua aspek pada kehidupan manusia. Mengingat tingginya investasi dan luas cakupan penerapannya, maka keberhasilan investasi dan kualitas sistem informasi yang di kembangkan adalah hal yang paling penting untuk penelitian dan praktek (Iivari, 2005).

Keberhasilan implementasi sistem tidak hanya dilihat pada aspek teknologinya namun juga dari sisi pengguna. Pada beberapa dekade yang lalu, gagalnya penerapan TI pada organisasi karena aspek teknisnya, seperti kualitas TI yang buruk yang banyak mengandung kesalahan-kesalahan sintak, kesalahan-kesalahan logik, dan bahkan kesalahankesalahan informasi. Walaupun pada saat ini kualitas teknis sistem informasi telah membaik, kegagalan penerapan sistem masih terdengar di beberapa perusahaan (Jogiyanto, 2007).

Sistem teknologi yang diterapkan pada organisasi menjadi komponen dalam organisasi bersama-sama dengan manusia. Manusia berinteraksi menggunakan TI dan interaksi ini menimbulkan masalah keperilakuan (behavioral). Kegagalan terjadi karena manusia menolak atau tidak ingin menggunakan TI.

Beberapa penelitiaan terdahulu menunjukkan bahwa perusahaan khususnya manager perlu untuk memahami faktor-faktor apa saja yang memicu perilaku individual terhadap TI (Jogiyanto, 2007).
Penelitian mengenai perilaku penggunaan TI telah di lakukan sejak tahun 1980-an. Jogiyanto (2007) mengelompokan penelitianpenelitian sistem informasi kedalam dua aliran. Aliran yang pertama adalah aliran yang memfokuskan penelitian pada penerimaan, adopsi, dan penggunaan dari sistem informasi. Aliran ini juga fokus pada antesedenanteseden atau penyebab-penyebab perilaku. Sedangkan, aliran yang kedua fokus pada kesuksesan implementasi di tingkat organisasi.

Aliran pertama di kelompokan lagi ke dalam 2 kelompok, yakni kelompok yang anteseden-anteseden perilaku berupa suatu perasaan (affect) dan kognitif (cognitive), misalnya: sikap, norma-norma, dan persepsi terhadap penggunaan.

Ada dua aliran pengukuran keberhasilan sistem. Aliran pertama, pengukuran keberhasilan sistem dengan menggunakan model penerimaan pengguna yang paling banyak digunakan oleh peneliti-peneliti yaitu, Technology Acceptance Model (TAM). TAM merupakan model pendekatan lain yang di susun (Davis, 1989) untuk menjelaskan penerimaan teknologi yang akan digunakan oleh pengguna teknologi. TAM juga digunakan oleh (Venkatesh et al., 2003) yang telah menguji perilaku pengguna dan penerimaan sistem dari berbagai perspektif.

Adapun kelompok yang kedua adalah kelompok yang anteseden-anteseden perilaku lebih berupa suatu proses, misalnya proses penilaian, proses partisipasi dan keterlibatan serta proses mencocokan teknologi dengan tugasnya. Beberapa teori dan model dari penelitian-penelitian dalam kelompok yang anteseden-antesedennya berupa suatu proses antara lain: model penyelesaian adaptasi pemakai (coping model of user adaptation) oleh Beaudry dan Pinsioneault (2005), partisipasi dan keterlibatan pemakai oleh Barki dan Hartwick (1994), model kesesuaian tugas-teknologi (task-technology fit) oleh Goodhue dan Thompson (1995).

Semakin berkembangnya TI juga meningkatkan penelitian mengenai kesuksesan suatu sistem TI. Banyaknya penelitian yang dilakukan menghasilkan berbagai macam 
model. Banyak di antara peneliti mengembangkan model baru dengan menggabungkan beberapa variabel dari konstruk pengukuran yang berbeda. Hasil dari penelitain tersebut bermacam-macam dan penggunaaan variabel dari masing-masing konstruk disesesuaikan dengan karakteristik dan juga sifat dari sistem teknologi informasi yang diteiliti.

Dengan tidak konsistennya pengujian model yang dilakukan di beberapa bidang penelitian tersebut, membuka peluang untuk dikembangkan lebih lanjut pada objek penelitian yang berbeda. Pengembangan penelitian ini masih belumlah baik, karena beberapa dari penelitian tersebut tidak mempertimbangkan sifat penggunaan sistem informasi.

PT. PLN merupakan salah satu perusahaan milik negara dengan operasional perusahaan menyediakan listrik di seluruh penjuru Indonesia. Untuk mengembangkan perusahaan PT. PLN telah mengimplememtasikan sistem berbasis ERP. Dalam rangka mengoptimalkan kinerja perusahaan baru-baru ini PT. PLN menngembakan suatu sistem baru yaitu sistem informasi anggran yang disebut "SmartOne".

Penerapan sistem informasi anggaran ini bersifat mandatori atau wajib.

SmartOne adalah satu aplikasi sistem teknologi yang baru diterapkan di PLN dan menjadi satu sistem yang penting dalam kegiatan operasional perusahaan. Oleh karena penerapannya harus berjalan dengan efektif, maka sistem ini menghubungkan beberapa sistem lain yang diterapkan di dalam perusahaan. Implementasi SmartOne secara teknis belum mengalami pengujian terhadap penerapannya.

Alasan selanjutnya adalah pada penelitian ini mencoba untuk melakukan penelitian mengenai kesuksesan dan keberterimaan suatu sistem yang baru diterapkan pada perusahaan untuk dapat menilai hasil dari implementasi sistem tersebut. Penelitian ini mencoba menggabungkan dua model pengukuran kesuksesan yang sering digunakan, yaitu model kesuksesan DeLone McLean yang di kemukakan oleh DeLone dan McLean (1992) dan Teory Accepted Model (TAM) oleh Davis (1989).

\section{METODE PENELITIAN}

Penelitian ini bertujuan untuk menguji faktor-faktor yang mempengaruhi kesuksesan implementasi dan keberterimaan sistem anggaran. Faktor-faktor yang diuji pada penelitian ini antara lain, kuatitas sistem, kualitas informasi, persepsi pengguna, persepsi kemudahan penggunaan, kepuasan pengguna, dampak individu. Selanjutnya faktor-faktor tersebut dijadikan sebagai indikator pengukuran dan menyusun suatu model penelitian. Adapun model penelitian yang dikembangkan dapat dilihat pada gambar di bawah ini.

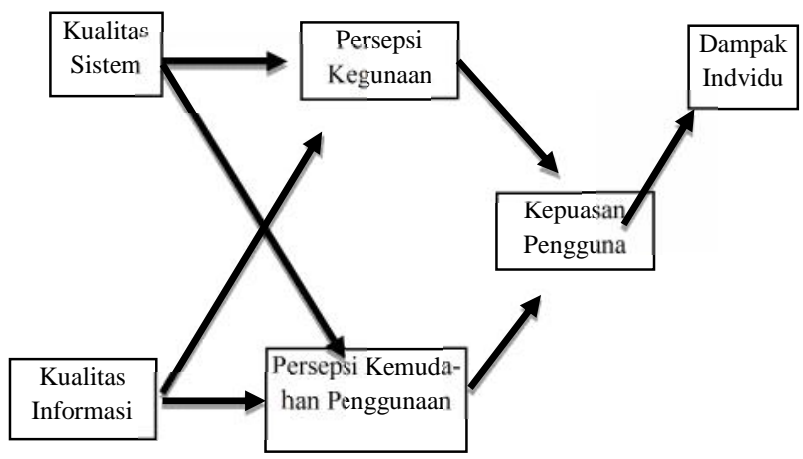

Gambar 1 Model Penelitian

Penelitian ini mencoba menerangkan pengaruh dari faktor-faktor kualitas sistem informasi, kualitas informasi terhadap kegunaan persepsi, dan kemudahan penggunaan persepsi, kemudian menilai kedua variabel tersebut terhadap kepuasan pengguna yang kemudian akan berpengaruh pada dampak individu yang selanjutnya memberi dampak terhadap organisasi pada penggunaan sistem informasi anggaran di PT. PLN Persero.

Berdasarkan model penelitian di atas maka selanjutnya dituangkan kedalam hipotesis penelitian sebagai berikut:

H1a : Kualitas sistem (system quality) mempunyai pengaruh positif terhadap kegunaan perspesi (perceived usefulness).

H1b : Kualitas sistem (system quality) mempunyai pengaruh positif terhadap kemudahan penggunaan persepsi (perceived ease of use).

$\mathrm{H} 2 \mathrm{a}$ : Kualitas informasi (information quality) mempunyai pengaruh positif terhadap persepsi kegunaan (perceived usefulness).

$\mathrm{H} 2 \mathrm{~b}$ : Kualitas informasi (information quality) mempunyai pengaruh positif terhadap per- 
sepsi kepuasan penggunaan (perceived ease of use).

H3 : Kegunaan persepsi (perceived usefulness) mempunyai pengaruh yang positif terhadap kepuasan pengguna (user satisfaction).

$\mathrm{H} 4$ : Kemudahan penggunaan persepsian (perceived ease of use) memiliki pengaruh positif terhadap kepuasan pengguna (user satisfaction).

H6 : Kepuasan pengguna (user satisfaction) mempunyai pengaruh yang positif terhadap dampak individu (individual impact).

Penelitian ini menggunakan data primer yang langsung diperoleh dari karyawan dari Divisi Keuangan, Anggaran, dan Akuntansi, Distribusi serta Perencanaan PT. PLN Persero yang terpilih menjadi sampel penelitian.

Metode pengumpulan data dalam penelitian ini menggunakan teknik pengumpulan data survei untuk mendapatkan data opini setiap karyawan. Survei (survey) atau lengkapnya self-administered survey adalah metode pengumpulan data primer dengan memberikan pertanyaan-pertanyaan kepada responden individu (Jogiyanto, 2005).

Populasi dalam penelitian ini adalah semua pegawai pada Divisi Keuangan, Anggaran, dan Akuntansi, Distribusi serta Perencanaan PT. PLN Persero sebagai pengguna sistem informasi anggaran Smartone terdiri dari orang yang secara aktif menggunkan aplikasi SmartOne dalam kinerjanya.

Sampel dalam penelitian ini diambil dengan menggunakan metode sampel bertujuan (purposive sampling) dengan judgment sampling. Sampel bertujuan (purposive sampling) dilakukan dengan mengambil sampel dari populasi berdasarkan suatu kriteria tertentu. Kriteria yang digunakan dapat berdasarkan pertimbangan (judment) tertentu atau jatah (quota) tertentu (Jogiyanto, 2005).

Judgment sampling berarti sampel dipilih berdasarkan penilaian peneliti bahwa untuk menjadikan sesuatu atau seseorang menjadi sampel penelitiannya. Judgment sampling yaitu merupakan metode sampling berdasarkan pertimbangan tertentu dengan kriteria yang ditetapkan (Jogiyanto, 2008). Kriteria yang ditetapkan sebagai sampel dalam penelitian ini adalah sebagai berikut
1. Responden merupakan pegawai dari Divisi Keuangan, Anggaran, dan Akuntansi, Distribusi, Perencanaan dan Kosntruksi PT. PLN Persero

2. Responden merupakan pegawai dari Divisi Keuangan, Anggaran, dan Akuntansi, Distribusi,Perencanaan dan Kosntruksi PT. PLN Persero yang merupakan user dan menggunakan sistem informasi anggaran dalam kinerjanya

3. Responden merupakan pegawai dari Divisi Keuangan, Anggaran, dan Akuntansi, Distribusi serta Perencanaan PT. PLN Persero yang telah mendapatkan pelatihan dalam menjalankan sistem informasi anggaran.

Sampel dalam penelitian ini adalah pegawai Divisi Keuangan, Anggaran, dan Akuntansi, Distribusi, Perencanaan dan Konstruksi PT. PLN Persero yang telah mendapatkan pelatihan dan juga aktif menggunakan aplikasi SmartOne pada kinerjanya. Hal ini bertujuan agar responden yang akan digunakan dalam penelitian ini dapat memberikan jawaban yang sesuai dengan kebutuhan penelitian mengenai penerimaan aplikasi SmartOne oleh pegawai PT. PLN Persero

Penelitian ini mengunakan konstruk dari beberapa penelitian sebelumnya. Maka, perlu untuk dilakukan pengujian terkait konstrukkonstruk pertanyaan yang akan disebarkan melaluii kuisioner. Pengujian ini dilakukan dengan mengadakan pilot test.

Pilot test akan dibagikan secara acak kepada beberapa pegawai di Divisi Keuangan PT PLN di Area Purwokerto. Selain itu, kuesioner yang diambil dari penelitian sebelumnya dalam bentuk bahasa inggris akan diterjemahkan secara individu oleh peneliti. Hasil terjemahan kuesioner tersebut akan didiskusikan kepada pihak yang memiliki keahlian di bidang tata bahasa untuk mendapatkan kuesioner yang benar dan konsisten.

Dari 8 kuesioner yang dibagikan secara langsung, 6 kuesioner kembali dan 2 kuesioner tidak kembali. Sehingga, jumlah kuesioner yang dapat diolah adalah sebesar $75 \%$. Hasil dari pilot test baik karena semua pegawai memahami maksud dari setiap pertanyaan yang diajukan. 
Penelitian ini mengukur kesuksesan dan keberterimaan suatu sistem teknologi informasi dengan menggabungkan dua model kontruk. Penelitian ini mencoba menggabungkan antara model kesuksesan sistem informasi yang dikemukakan oleh (DeLone dan McLean, 1992) yang digabungkan dengan Model Technology Acceptance Model (TAM) oleh (Davis, 1989). Penelitian ini mengambil beberapa konstruk dari kedua model tersebut yang dianggap dapat mengukur kesuksesan dan juga keberterimaan sistem tersebut. Konstruk dari model kesuksesan sistem informasi yang dikemukakan oleh (DeLone dan McLean, 1992) yang digunakan pada penelitian ini adalah kualitas sistem, kualitas informasi, kepuasan penguna, dampak individu dan dampak organisasi sedangkan dari model Technology Acceptance Model (TAM) oleh (Davis, 1989) konstruk yang digunakan dalam penelitian ini adalah kegunaan persepsi dan juga kemudahan penggunaan persepsi.

Adapun devinisi operasional konstruk yang dipilih sebagai varaiabel dalam peneltian ini adalah:

1. Kualitas sistem (system quality) adalah persepsi pengguna terhadap seberapa baik sistem informasi tersebut tersedia. Indikator yang digunakan untuk mengukur kualitas sistem diadaptasi dari penelitian (Iivary, 2005) yang menggunakan lima indikator penilaian yaitu kehandalan, akurasi data, waktu respon dan turnover cepat, mudah digunakan, konektivitas terhadap departemen lain (konektivitas antar bagian). Selanjutnya akan diukur menggunakan skala litker lima point.

2. Kualitas informasi (information quality) digunakan untuk mengukur kualitas keluaran dari sistem informasi sehingga dapat digunakan oleh pengguna. Indikator yang digunakan untuk mengukur kualitas sistem diadaptasi dari penelitian (Iivary, 2005) yang menggunakan lima indikator penilaian yaitu keakuratan, tepat waktu, kegunaan, mudah dipahami dan kelengkapan. Selanjutnya akan diukur menggunakan skala litker lima point.

3. Kegunaan persepsi (perceived usefulness) didefinisikan sebagai sejauh mana seseo- rang percaya bahwa menggunakan sistem teknologi akan meningkatkan kinerja pekerjaannya. Indikator yang digunakan untuk mengukur persepsi kegunaan diadaptasi dari penelitian (Davis et al., 1989) yang menggunakan lima indikator penilaian yaitu bekerja dengan lebih cepat, performa pekerjaan, meningkatkan produktifitas, efektif, membuat pekerjaan lebih mudah dan bermanfaat. Selanjutnya akan diukur menggunakan skala likert lima poin.

4. Kemudahan penggunaan persepsi (perceived ease of use) didefiniskan sebagai sejauh mana seseorang percaya bahwa menggunakan suatu sistem teknologi akan bebas dari usaha. Indikator yang digunakan untuk mengukur persepsi kegunaan diadaptasi dari penelitian Davis et al., (1989) yang menggunakan lima indikator penilaian yaitu mudah untuk dipelajari, dapat dikontrol, jelas dan mudah dipahami, flexible, mudah untuk dikuasai dan mudah untuk digunakan.

5. Kepuasan pemakai (user satisfaction) adalah respon pemakaian terhadap penggunaan keluaran sistem informasi. Pemakaian (use) harus mendahului kepuasan pemakain (user satisfaction) sebagai satu proses yang menghasilkan kepuasan dari penggunaan tersebut. Instrumen yang digunakan dalam mengukur kepuasan pengguna berdasarkan DeLone dan McLean (1992) yang menggunakan lima item pengukuran yaitu, kepuasan menyeluruh (overall satisfaction), kepuasan informasi, kesenangan (enjoyment), kepuasan komponen pendukung dan kegunaan.

6. Dampak individual (individual impact) merupakan efek dari informasi terhadap perilaku pemakai. Dampak (impact) berhubungan erat dengan kinerja, yaitu meningkatkan kinerja individual pemakai sistem. Instrument yang digunakan dalam mengukur dampak individu berdasarkan penelitian yang dilakukan oleh DeLone dan McLean (1992). Instrumen yang digunakan sebanyak 5 item yaitu, pemahaman informasi (information understanding), akurasi interpretasi (accurate inter- 
pretation), peningkatan produktivitas individual (improved individual productivity), kinerja tugas (task performance), kualitas rencana-rencana (quality of plans).

Metode analsis data yang digunakan dalam penelitian ini adalah teknik analisis Partial Least Square (PLS). PLS adalah metode umum untuk mengestimasi path model yang menggunakan konstruk laten dengan multiple indikator dan sample yang digunakan tidak harus besar, pendekatan PLS adalah distribution free (tidak mengasumsikan data berdistribusi tertentu, dapat berupa nominal, kategori, ordinal, interval dan rasio). Selain itu PLS juga dapat digunakan sebagai konfirmasi teori juga dapat digunakan untuk menjelaskan ada atau tidaknya hubungan antara variabel laten (Ghozali, 2008).

PLS merupakan metoda analisis persamaan SEM berbasis varian yang secara simultan dapat melakukan pengujian model sekaligus pengujian model struktural model. Pengukuran yang nantinya akan digunakan untuk menguji validitas dan reliabilitas, sedangkan hasil dari pengujian struktural juga akan digunakan sebagai penguji kausalitas seperti pengujian hipotesis dengan model prediksi.

\section{HASIL DAN PEMBAHASAN}

Tujuan dari penelitian ini adalah untuk mengetahui kesuksesan dan keberterimaan implementasi sistem sistem infromasi anggaran, peneliti melakukan investigasi dengan mengunjungi kantor distribusi dan beberapa kantor wilayah untuk menginvestigasi alasan belum optimalnya sistem tersebut digunakan. Selanjutnya, berdasarkan investigasi awal yang telah dilakukan maka diperoleh informasi PT. PLN (Persero) wilayah Jawa Tengah yang secara penuh telah menggunakan sistem tersebut dan menunjukkan peningkatan performa pada 6 bulan terakhir.

Selanjutnya, peneliti melakukan investigasi langsung yaitu dengan kuesioner. Kuisoner merupakan teknik yang tepat karena dapat menghemat biaya dan waktu selain itu juga dapat menunjukkan perbedaanperbedaan pada setiap responden.
Responden dalam penelitian ini adalah pegawai PT. PLN (Persero) wilayah Jawa Tengah Devisi Keuangan, Anggaran, Distribusi, dan Kosntruksi yang tersebar pada beberapa rayon. Dengan kriteria pegawai tersebut telah menerima pelatihan, memiliki account dan sebagai pengguna (user) sistem SmartOne.

Pada setiap kantor area kerja disatu kabupaten atau kota terdapat sekitar 40 user SmartOne yang menggunakan sistem ini untuk kinerjanya. Sehingga tidak ada spesifikasi khusus yang digunakan bagi responden. Seluruh user SmartOne dalam satu kantor area kerja menjadi responden penelitian tanpa terkecuali.

Dari 40 kuesioner yang disebarkan secara langsung pada kantor kerja PT. PLN (Persero) wilayah Jawa Tengah, terkumpul sebanyak 35 kuesioner yang berasal dari kantor rayon, sebagai pengguna aktif sistem sistem infromasi anggaran. Dari 35 kuesioner yang diterima, 35 kuesioner yang dapat digunakan sebagai data penelitian.

Selanjutnya kuisioner tersebut diolah untuk menhasilkajn informasi yang dibutuhkan. Pertama-tama dilakukan analysis statistic deskrip-tif untuk menggungkap gambaran data yang dikumpulkan. Hasil analisis statistik deskriptif berguna untuk mendukung penafsiran atau interpretasi hasil analisis dengan teknik lainnya. Deskripsi dilakukan dengan cara menginterpretasikan hasil pengolahan data melalui tabulasi frekuensi guna mengungkapkan kecenderungan data nominal empirik rata-rata hitung (mean) pada setiap variabel.

Tabel 1 Descriptive Statistic

\begin{tabular}{llllll}
\hline \multicolumn{6}{l}{ Descriptive Statistics } \\
\hline Konstruk & N & Min & Max & Mean & Std. Dev \\
\hline KS & 35 & 2.00 & 4.60 & 3.8000 & .51235 \\
\hline KI & 35 & 1.60 & 5.00 & 3.8788 & .60815 \\
\hline PK & 35 & 2.00 & 4.60 & 3.6667 & .55151 \\
\hline PKP & 35 & 2.00 & 4.50 & 3.5657 & .47496 \\
\hline KP & 35 & 2.20 & 5.00 & 3.5273 & .60378 \\
\hline DI & 35 & 2.00 & 5.00 & 3.8788 & .60563 \\
\hline Valid N & 35 & & & \\
\hline Sumber: data diolah
\end{tabular}


Berdasarkan tabel di atas terlihat bahwa jawaban responden pada setiap item pertanyaan yang diajukan menunjukkan informasi bahwa seluruh konstruk penelitian memberikan hasil yang baik. Hal ini ditunjukkan pada nilai standar deviasi yang lebih kecil dari nilai rata-rata (mean). Selain itu, sebaran data akanpersepsi responden atas jawaban kuesioner juga baik.

Langkah selanjutnya melakukan pengujian terhadap hasil penelitian. Pengujian hasil dengan mengukur hubungan kausal antar variabel dilakukan dengan menggunakan PLS. Maka terlebih dahulu akan dibahas mengenai uji validitas yang dilakukan terhadap instrument penelitian. Pada uji validitas ada dua jenis, yaitu validitas konvergen dan validitas diskriminan.

Untuk pengukuran validitas konvergen rule of thumb yang digunakan adalah outer loading $>0,70$, communality $>0,5$ dan average variance extracted (AVE) > 0,5 (Chin, 1995). Semakin tinggi niliai faktor loading, maka semakin penting peranan loading dalam mengintrepertasikan matrik faktor. Pada tabel dibawah ini akan disajikan hasil uji validitas konvergen pada setiap instrumen penelitian.

Tabel 2 Hasil Uji Validitas Instrumen

\begin{tabular}{lclc}
\hline Instrument & AVE & Communality & Ket \\
\hline Individu & 0.709610 & 0,70961 & Valid \\
\hline Informasi & 0.758867 & 0,758867 & Valid \\
\hline Kegunaan & 0.692466 & 0,692465 & Valid \\
\hline Kemudahan & 0.501644 & 0,501644 & Valid \\
\hline Kepuasan & 0.691953 & 0,691953 & Valid \\
\hline Sistem & 0.552822 & 0,552823 & valid \\
\hline
\end{tabular}

Sumber: data diolah

Untuk hasil loading AVE dan communality dari hasil pengolahan dengan menggunakan partial least square, memiliki skor yang sama. Adapun untuk outer loading pada setiap variabel Berdasarkan analisis tabel diketahui, bahwa dari faktor loading atau outer loading secara keseluruhan indikator konstruk yang diujikan sudah valid, karena nilai dari tiap konstruk lebih dari 0,5

Untuk menilai validitas instrumen dapat pula dilakukan dengan uji validitas diskriminan. Validitas diskriminan berhu- bungan dengan prinsip bahwa pengukuran pada tiap konstruk yang berbeda seharusnya tidak berkorelasi dengan tinggi. Adapun pengujian validitas jika dilihat dari nilai cross loading, hasilnya sama halnya dengan faktor loading pada semua indikator yang mengukur konstruk telah valid. Hal ini terlihat pada nilai cross loading, pada setiap instruemen lebih besar dari 0,70 .

Selanjutnya adalah uji relibialitas, adapun hasil pengujian ini untuk mengetahui reliabel atau tidaknya alat ukur yang digunakan dalam penelitian ini, maka diperoleh hasil yang memenuhi syarat sehingga dapat dinyatakan bahwa indikator yang dipakai dalam penelitian ini adalah reliable.Uji reliabilitas dilakukan dengan dua metode, yaitu Cronbach's alpha dan Composite reability. Rule of thumb untuk dua metode ini mengharuskan nilai Alpha dan Composite reablity harus lebih besar dari 0,7. Melihat nilai composite reliability dari blok indikator yang mengukur konstruk. Berikut adalah nilai composite reliability pada output.

Tabel 3 Hasil Uji Relibialitas

\begin{tabular}{llll}
\hline \multicolumn{1}{c}{ Instrumen } & $\begin{array}{c}\text { Composite } \\
\text { Reliability }\end{array}$ & $\begin{array}{c}\text { Cronbachs } \\
\text { Alpha }\end{array}$ & Ket \\
\hline Individu & 0.923636 & 0.895471 & Reliabel \\
\hline Informasi & 0.939883 & 0.919381 & Reliabel \\
\hline Kegunaan & 0.917843 & 0.887580 & Reliabel \\
\hline Kemudahan & 0.854958 & 0.794614 & Reliabel \\
\hline Kepuasan & 0.917828 & 0.887190 & Reliabel \\
\hline Sistem & 0.859635 & 0.795207 & Reliabel \\
\hline
\end{tabular}

Sumber: data diolah

Tabel pengujian reabilitas di atas menunjukkan bahwa nilai composite reliability untuk semua konstruk adalah lebih dari 0,7 yang menunjukkan bahwa semua konstruk pada model yang diestimasi memenuhi kriteria discriminant validitydan reliable. Nilai composite reliability yang terendah adalah sebesar 0.854958 pada konstruk kemudahan.

Uji reliabilitas juga bisa diperkuat dengan Cronbach's Alpha di mana output SmartPLS pada Tabel pengujian reablititas menunjukkan bahwa setiap instrumen penelitian reliabel. Nilai yang disarankan adalah di atas 0,7 
dan pada tabel di atas menunjukkan bahwa nilai Cronbach's Alpha untuk semua kontruk berada lebih dari 0,7 . Nilai terendah adalah sebesar 0.794614 pada instrumen kemudahan. Pengujian model struktural dilakukan untuk memprediksi hubungan kausal antar variabel atau pengujian hipotesis. Model struktural dievaluasi dengan menggunakan $\mathrm{R}^{2}$ untuk variabel dependen dan koefisien pada path ( ) untuk variabel independen yang kemudian dinilai signifikansinya berdasarkan nilai $T$ statistic setiap path (Hartono dan Abdullah, 2009). Pada Tabel 4 dibawah ini akan disajikan nilai R Square dan redundancy.

Tabel 4 R Square

\begin{tabular}{ccc}
\hline Keterangan & R Square & Redundancy \\
\hline DI & 0,3849 & 0,2588 \\
\hline KI & 0 & 0 \\
\hline KP & 0,659 & 0,3796 \\
\hline KS & 0 & 0 \\
\hline PK & 0,6782 & 0,3133 \\
\hline PKP & 0,7111 & 0,2229 \\
\hline
\end{tabular}

Sumber: data diolah

Nilai R square (R2) semakin tinggi menunjukkan hasil yang lebih baik. Dari tabel diatas dapat diketahui bahwa nilai R Squarekegunaan persepsi (PK) adalah sebesar 0,6782 $(67,8 \%)$. Hal ini berarti variabel (konstruk) kegunaan persepsi (perceived usefulness) dapat dijelaskan oleh variabel kualitas sistem (system quality), dan kualitas informasi (information quality), sebesar 0,6782 atau $67,8 \%$, sedangkan sisanya yaitu 0,3218 atau $32,2 \%$ dijelaskan oleh variabel lain.

Nilai $\mathrm{R}^{2}$ dari kemudahan penggunaan persepsi (perceived ease of use) adalah 0,7111 atau $71,11 \%$ (tabel 5). Hal ini menunjukkan bahwa variabel kemudahan penggunaan persepsi dapat dijelaskan oleh variabel kualitas sistem (system quality), an kualitas informasi (information quality), sebesar $71,11 \%$ dan sebesar 28,89\% dijelaskan oleh variabel lain.

Untuk nilai $\mathrm{R}^{2}$ pada kepuasan pengguna (user satisafaction) adalah 0,659 atau sebesar $65,9 \%$. Hal ini menunjukkan bahwa kepuasan pengguna dapat dijelaskan oleh variabel kegunaan persepsi (perceived usefulness) dan kemudahan penggunaan persepsi (perceived ease of use), sebesar $65,9 \%$ dan sisanya $34,1 \%$ dijelaskan oleh variabel lain.

Nilai $\mathrm{R}^{2}$ dari dampak individu (individual impact) adalah 0,3849atau 38,49\%. Hal ini menunjukkan bahwa variabel dampak individu (individual impact) dapat dijelaskan oleh variabel kepuasan pengguna (user satisfaction), sebesar $38,49 \%$ dan sebesar $61.51 \%$ dijelaskan oleh variabel lain.

Nilai redundancy pada tabel tersebut menunjukkan nilai predictive relevance yang akan mengukur seberapa baik nilai observasi dihasilkan oleh model dan juga estimasi parameternya. Nilai redundancy lebih dari nol menunjukkan model memilikipredictive relevance. Dengan demikian konstruk kegunaan persepsi, kemudahan kegunaan persepsi, kepuasan pengguna, dampak individu dan dampak organisasimemiliki predictive relevancekarena nilainya lebih dari nol seperti yang tampak pada table $R$ Square.

Langka terakhir pada pada pengujian ini adalah uji hipotesisi. Hal ini dilakukan untuk memprediksi hubungan kausalitas antar variabel laten seperti yang sudah dijelaskan pada bab III, dalam penelitian ini dilakukan dengan melalui proses bootstraping, dengan parameter uji T-statistic. Model struktural dalam PLS dievaluasi dengan menggunakan $\mathrm{R}^{2}$ untuk konstruk dependen, nilai koefisien path atau $t$ values tiap path untuk uji signifikansi antar konstruk dalam model struktural.

Pada gambar skema hasil bootstraping dengan menggunakan software Partial Least Square, dapat dilihat pada Gambar 1 sebelumnya. Maka untuk lebih jelasnya akan disajikan hasil pengujian hipotesis yang diperoleh dengan menggunakan PLS akan disajikan dalam bentuk tabel seperti yang tampak pada tabel dibawah ini. 
Tabel 5 Hasil Pengujian Hipotesis

\begin{tabular}{lccccc}
\hline \multicolumn{1}{c}{ Hipotesis } & $\begin{array}{c}\text { Original } \\
\text { Sample }(O)\end{array}$ & $\begin{array}{c}\text { Sample } \\
\text { Mean }(M)\end{array}$ & STDEV & STERR & $(\mid$ I \\
STERR $\mid)$
\end{tabular}

Sumber: data diolah

Pada Tabel diatas disajikan hasil path coeficient yang dihasilkan melalui Smart PLS. Hipotesis yang dikembangkan dalam penelitian dapat diuji signifikansi konstruk penelitian. Selanjutnya akan dijadikan pertimbangan diterima suatu hipotesis dengan menilai signifikansi konstruk dengan suatu kriteria, adapun kriteria signifikansi pada penelitian ini adalah nilai T-statistik > 1,65. Untuk lebih jelasnya, di bawah ini terdapat interpretasi masingmasing hipotesis

H1a : Kualitas sistem (system quality) mempunyai pengaruh positif terhadap kegunaan perspesi (perceived usefulness)

Pada Tabel 5 di atas menunjukkan bahwa hubungan antara kualitas sistem dengan kegunaan persepsi pada penelitian ini tidak signifikan dengan T-statistik sebesar $1.318810(<1,65)$. Nilai original sample estimate adalah positif yaitu sebesar 0.214696 yang menunjukkan bahwa arah hubungan antara kualitas sistem dengan kegunaan persepsi adalah positif. Dengan demikian hipotesis H1a dalam penelitian ini tidak terdukung.

H1b: Kualitas sistem (system quality) mempunyai pengaruh positif terhadap kemudahan penggunaan persepsi (perceived ease of use)

Berdasarkan hasil perhitungan SmartPLS pada Tabel 5 di atas menunjukkan bahwa hubungan antara kualitas sistem dengan kemudahan penggunaan persepsi adalah signifikan dengan T-statistik sebesar 3.939165 (> 1,65). Dan untuk nilai original sample estimate adalah positif yaitu sebesar 0.514567 . Hal ini menunjukkan bahwa arah hubungan antara kualitas sistem dengan kemudahan penggunaan persepsi adalah positif. Dengan demikian hipotesis $\mathrm{H} 1 \mathrm{~b}$ dalam penelitian ini terdukung.

H2a : Kualitas informasi (information quality) mempunyai pengaruh positif terhadap persepsi kegunaan (perceived usefulness).

Selanjutnya pada hasil Tabel 5 di atas menunjukkan bahwa hubungan antara kualitas informasi dengan kegunaan persepsitidak signifikan dengan T-statistik sebesar 1.529222 $(<1,65)$. Namun nilai original sample estimate adalah positif yaitu sebesar 0.419055 yang menunjukkan bahwa arah hubungan antara kualitas informasi dengan kegunaan persepsi adalah positif. Dengan demikian hipotesis $\mathrm{H} 2 \mathrm{a}$ dalam penelitian ini tidak terdukung.

H2b: Kualitas informasi (information quality) mempunyai pengaruh positif terhadap persepsi kepuasan penggunaan (perceived ease of use.

Tabel 5 di atas menunjukkan bahwa hubungan antara kualitas informasi dengan kemudahan penggunaan persepsi adalah signifikan dengan T-statistik sebesar 4.812237 (> 1,65). Nilai original sample estimate adalah positif yaitu sebesar 0.440778 yang menunjukkan bahwa arah hubungan antara kualitas informasi dengan kemudahan penggunaan persepsiadalah positif. Dengan demikian hipotesis H2b dalam penelitian ini terdukung.

H3 : Kegunaan persepsi (perceived usefulness) mempunyai pengaruh yang positif terhadap kepuasan pengguna (user satisfaction)

Berdasarkan table sebelumnya menunjukkan bahwa hubungan antara kegunaan persepsi dengan kepuasan pengguna adalah signifikan dengan T-statistik sebesar $3.633688(>1,65)$. 
Nilai original sample estimate adalah positif yaitu sebesar 0.546957 yang menunjukkan bahwa arah hubungan antara kegunaan persepsi dengan kepuasan pengguna adalah positif. Dengan demikian hipotesis $\mathrm{H} 3$ dalam penelitian ini terdukung.

H4 : Kemudahan penggunaan persepsian (perceived ease of use) memiliki pengaruh positif terhadap kepuasan pengguna (user satisfaction)

Selanjutnya pada tabel atas menunjukkan bahwa hubungan antara kemudahan penggunaan persepsi dengan kepuasan pengguna adalah signifikan dengan $\mathrm{T}$-statistik sebesar $1.729649(>1,65)$. Nilai original sample estimate adalah positif yaitu sebesar 0.314508 yang menunjukkan bahwa arah hubungan antara kemudahan penggunaan persepsi dengan kepuasan pengguna adalah positif. Dengan demikian, hipotesis $\mathrm{H} 4$ dalam penelitian ini terdukung.

H5 : Kepuasan pengguna (user satisfaction) mempunyai pengaruh yang positif terhadap dampak individu (individual impact)

Pada Tabel 4.9 diatas untuk hipotesis 6, kepuasan pengguna dengan dampak individu menunjukkan hubungan yang signifikan hal ini dilihat pada hasil T-statistik sebesar 6.896592 (> 1,65). Selanjutnya pada nilai original sample estimate adalah positif yaitu sebesar0.620379 yang menunjukkan bahwa arah hubungan antara kepuasan pengguna dengan dampak individu. Makaberdasarkan hasil tersebut $\mathrm{H} 5$ dalam penelitian ini terdukung.

Lebih lanjut, dari tiga variabel yang mempengaruhi kegunaan persepsi (kegunaan) secara langsung, yaitu kualitas sistem, kualitas informasi dan kemudahan penggunaan persepsi yang paling besar pengaruhnya adalah kualitas informasi karena mempunyai nilai original sample estimate tertinggi yaitu sebesar 0.419055 dibandingkan dua variabel yang lain. Dengan demikian kualitas informasi merupakan variabel yang paling dominan dalam mempengaruhi kegunaan persepsi dariuser.

Selanjutnya pada nilai original sample estimate pada dua variabel yang mempengaruhi kemudahaan penggunaan persepsi nilai tertinggi diperoleh pada nilai kualitas sistem sebesar 0.514567 yang lebih besar dari nilai kualitas informasi yaitu 0.440778. Maka kualitas sistem memiliki pengaruh yang lebih besar terhadap kemudahan penggunaan persepsi dibandingkan dengan kualitas informasi.

Kegunaan persepsi memiliki pengaruh yang lebih besar terhadap kepuasan pengguna dibandingkan dengan kemudahan penggunaan persepsi. Hal ini ditunujkkan pada nilai original sample estimate pada table sebelumnya diatas. Nilai original sample estimateuntuk variabel kegunaan persepsi sebesar 0.546957, nilai ini lebih tbesar dibandingkan dengan nilai variabel kemudahaan penggunaan persepsi sebesar 0.314508 . sedangkan untuk variabel yang paling tidak dominan adalah kualitas sistem yaitu dengan original sample estimate terkecil yaitu sebesar 0.214696 .

Untuk lebih jelasnya hasil hipotesis akan disajian dalam Tabel 6 berikut:

Tabel 6 Hasil Hipotesis

\begin{tabular}{lcl}
\hline \multicolumn{1}{c}{ Hipotesis } & Keterangan \\
\hline $\begin{array}{l}\text { H1b : kualitas sistem } \\
\text { penggunaan persepsi }\end{array}$ & & \\
\hline $\begin{array}{l}\text { H2b : kualita Informasi } \\
\text { penggunaan persepsi }\end{array}$ & kemudahan & Signifikan \\
\hline $\begin{array}{l}\text { H3 : kegunaan persepsi } \\
\text { pengguna }\end{array}$ & kepuasan & Signifikan \\
\hline $\begin{array}{l}\text { H4 : kemudahan penggunaan } \\
\text { persepsi kepuasan pengguna }\end{array}$ & Signifikan \\
\hline $\begin{array}{l}\text { H5 : kepuasan pengguna } \\
\text { individu }\end{array}$ & dampak & Signifikan \\
\hline $\begin{array}{l}\text { H1a : kualitas sistem } \\
\text { persepsi }\end{array}$ & kegunaan & $\begin{array}{l}\text { Tidak } \\
\text { H2b : kualitas informasi } \\
\text { persepsi }\end{array}$ \\
\hline
\end{tabular}

Sumber: data diolah

Berdasarkan hasil analisis dengan menggunakan SmartPLS yang telah dilakukan sebelumnya maka terbukti bahwa penggunaan SmartOne pada penelitian ini dinyatakan sukses walaupun terdapat beberapa kendala dan juga hamabatan pada implementasinya. Berdasarkan hasil uji yang telah dilakukan dari 7 hipotesis yang diajukan pada penelitian ini, terdapat dua hipotesis yang tidak terdukung dan lima hipotesis lainnya terdukung. 
Hipotesis pertama pada penelitian ini menguji pengaruh kualitas sistem terhadap kegunaan persepsi pada implementasi sistem Ainformasi anggaran di PT. PLN (Persero). Secara statistik hipotesis pertama atau H1a tidak terdukung. Hal ini menunjukkan bahwa kualitas sistem SmartOne tidak memiliki pengaruh terhadap kegunaan persepsi user. Hal ini sejalan dengan penelitian sebelumnya yang dilakukan oleh (Brown dan Jayakody 2008 dan 2009). Persepsi kegunaan merupakan tingkat saat seseorang percaya bahwa dengan menggunakan sistem tertentu dapat meningkatkan kinerja. Hal ini tidak terjadi ketika sistem yang digunakan pada perusahaan tidak efisien. Dalam hal ini ketika fungsi sistem tersebut telah dipenuhi oleh sistem yang telah digunakan sebelumnya.

Berdasarkan teori perilaku yang diwajibkan (mandatory behavior) adalah perilaku yang bukan atas kemauannya sendiri tetapi karena memang tuntutan atau kewajiban dari pekerjaan pemanfaatan (Chin dan Todd, 1995). Penggunaan sistem yang bersifat mandatory tidak mempengaruhi persepsi pengguna walaupun kualitas sistem SmartOne baik. Maka kualitas sistem tidak menjadi prediktor yang baik terhadap kegunaan persepsi pengguna

Hal tersebut juga tidak berlaku pada hipotesis kedua (H1b) yang menguji pengaruh kualitas sistem terhadap kemudahan penggunaan persepsi. Berdasarkan hasil pengujian hipotesis yang telah dilakukan maka diperoleh hasil bahwa kualitas sistem memiliki pengaruh yang positif dan signifikan terhadap kemudahan kegunaan persepsi. Hal ini mendukung penelitian sebelumnya yang yang dilakukan oleh (Tzeng et.al, 2009), (Brown dan Jayakody, 2008), (Wang, 2008) dan (Ceng dan Chen, 2009).

Temuan ini mendukung Technologi Acceptance Model (TAM) oleh Davis (1989) yang menyatakan reaksi dan persepsi pengguna teknologi informasi dipengaruhi oleh variabel eskternal yaitu kualitas sistem informasi. Temuan ini memperkuat penelitian sebelumnya yaitu (Davis, 1989) dan (Adam et al, 1992) yang menyatakan bahwa kualitas sistem informasi berpengaruh terhadap per- sepsi kemudahan penggunaan. Lebih lanjut (Adam et al, 1992) menyatakan bahwa intensitas penggunaan dan interaksi antara pengguna dengan sistem menunjukkan kemudahan penggunaan.

Kemudahan penggunaan merupakan suatu kepercayaan tentang proses pengambilan keputusan. Jika pengguna percaya bahwa sistem informasi mudah digunakan, pengguna akan menggunakannya. Sebaliknya jika pengguna merasa percaya bahwa sistem informasi tidak mudah digunakan, pengguna tidak akan menggunakan. Jadi, dapat disimpulkan bahwa semakin tinggi kualitas sistem informasi yang tercermin dalam kemudahan penggunaan dalam menggunakan sistem informasi anggaran perusahaan, akan meningkatkan kinerja pengguna berdasarkan persepsi mereka.

Hipotesis ketiga pada penelitian ini menguji pengaruh kualitas informasi terhadap kegunaan persepsi. Berdasarkan pengujian yang telah dilakukan tidak terdapat pengaruh yang signifikan antara kualitas informasi terhadap kegunaan persepsi. Berdasarkan temuan dari hasil wawancara yang telah dilakukan, responden mengungkapkan banyaknya sistem yang diiplementasikan pada perusahaan membuat mereka tidak merasakan kegunaan dari SmartOne. Hal ini dikarenakan fungsi SmartOne telah mereka temukan pada sistem yang sebelumnya diterapkan yaitu SAP. Hasil ini sepertinya memberikan pemahaman bahwa implementasi sistem informasi pada konteks mandatory dan voluntary memiliki hasil yang berbeda khususnya pada pengukuran variabel kegunaan persepsi.

Hal ini didukung dengan teori perilaku yang diwajibkan (mandatory behavior) adalah perilaku yang bukan atas kemauannya sendiri tetapi karena memang tuntutan atau kewajiban dari pekerjaan pemanfaatan (Chin dan Todd, 1995). Penggunaan SmartOne oleh user dikarenakan kewajiban, sehingga pengguna tidak merasakan kegunaan dari sistem. Responden juga mengungkapkan bahwa penerapan sistem informasi anggaran kurang efektif dan informasi yang dihasilkan telah mereka peroleh dari sistem SAP. Maka pengguna tidak merasakan adanya manfaat dari informasi yang dihasilkan oleh SmartOne. 
Selanjutnya berdasarkan pengujian yang telah dilakukan untuk hipotesis $\mathrm{H} 2 \mathrm{~b}$ yang ditemukan pengaruh yang signifikan antara kualitas informasi dengan kemudahan penggunaan persepsi. Hal ini mendukung penelitian sebelumnya yang dilakukan oleh (Lu,.et.al, 2010), (Zaied, 2012), (Syaifuddin,. et.al, 2013). Perusahaan melakukan peningkatan sistem informasi guna memenuhi kebutuhan informasi yang semakin meningkat.

Hal ini tidak dipengaruhi oleh penggunaan sistem yang bersifat wajib. Didukung oleh ungkapkan responden berdasarkan hasil wawancara yang dilakukan mengatakan informasi yang dihasilkan oleh SmartOne memenuhi semua kebutuhan informasi pengguna. Dan juga sistem yang terintegrasi secara online memudahkan user dalam hal up date informasi dan mengontrol anggaran sehingga SmartOne adalah sistem yang bermanfaat dalam kinerja pengguna.

Pada hasil pengujian yang dilakukan, hipotesis $\mathrm{H} 3$ dan $\mathrm{H} 4$ pada penelitian ini terbukti. Terdapat pengaruh yang signifikan pada kegunaan persepsi dan kemudahan penggunaan persepsi terhadap kepuasan pengguna. Hal ini mendukung penelitian sebelumnya, (Bhattacherjee, 2001) menyatakan bahwa kegunaan dirasakan sebagai penentu kunci yang mempengaruhi pengguna untuk terus menggunakan sistem dan didukung oleh penelitian lainnya oleh (Seddon, 2001, Brown dan Jayakody; 2008, Hussein et.al, Kang dan Lee, 2010).

Dalam beberapa studi sebelumnya, kepuasan pengguna telah diperiksa sebagai ukuran pengganti bagi keberhasilan atau kegagalan sistem Bailey \& Pearson (1983) dan Rivard \& Huff (1984).

Beberapa peneliti menggunakan konsep kepuasan pengguna sebagai variabel intervening antara kemudahan penggunaan dan kegunaan DeLone \& McLean (1992). Konsisten dengan (Seddon, 1997), penulis percaya bahwa kedua persepsi kemudahan penggunaan dan kegunaan mempengaruhi kepuasan secara langsung. Meskipun persepsi kemudahan penggunaan dan kegunaan merupakan respon kognitif pengguna ke sistem, kepuasan merupakan respon afektif. Hal ini dapat memakan waktu lebih lama untuk membentuk respon afektif dari respon kognitif. Pengguna kognitif dapat mengevaluasi kemudahan sistem penggunaan dan kegunaan relatif cepat jika mereka memahami karakteristik tujuannya. Kepuasan, bagaimanapun, muncul hanya setelah mereka telah menggunakan sistem. Akibatnya, reaksi afektif sering lebih stabil dari waktu ke waktu daripada respon kognitif, tidak mudah untuk memilih untuk merasakan cara tertentu terhadap objek tertentu pada waktu tertentu (Schelling, 1984). Singkatnya, orang cenderung lebih puas dengan sistem ketika mereka melihatnya sebagai mudah digunakan dan berguna dalam meningkatkan kinerja mereka (Baroudi et al, 1986) dan (Igbaria et al, 1994).

Berdasarkan wawancara yang telah dilakukan, responden mengatakan bahwa mereka puas dengan kegunaan SmartOne sebagai sistem anggaran. Didukung pula bahwa sistem SmartOne merupakan sistem yang mudah untuk digunakan. Kegunaan dan kemudahan kegunaan persepsi adalah indikator yang tepat untuk mengukur kepuasan pengguna dalam menggunakn sistem. Sehingga akan timbul keinginan untuk terus menggunakan sistem tersebut. Walaupun penggunaan SmartOne bersifat mandatori, dalam implementasinya pengguna merasa puas dengan sistem tersebut. Namun dikaitkan dengan temuan sebelumnya mengenai kegunaan persepsi yang dikarenakan pada penerapannya masih belum benar-benar dipisahkan antara fungsi sistem sebelumnya dengan sistem informasi anggaran sebagai sistem baru.

Berdasarkan hasil pengujian yang telah dilakukan sebelumnya untuk hipotesis H5 diperoleh hasil kepuasan pengguna SmartOne berpengaruh signifikan terhadap dampak individu. Hasil ini mendukung penelitian Radiyo dan Zulaikha (2007), Roldan dan Leal (2003), Livari (2005) dan juga penelitian Mc Gill et al. (2003).

Dalam beberapa studi sebelumnya, kepuasan pengguna telah digunakan sebagai ukuran pengganti bagi keberhasilan atau kegagalan sistem. Kepuasan pengguna menjadi respon pengguna setelah menggunakan sistem baru. Maka pengguna merasakan manfaat 
langsung dari kepuasan pengguna dalam menggunakan sistem ini, seperti semakin efektif dalam bekerja yang berdampak pada tercapainya tujuan organisasi dan meningkatnya kinerja organisasi.

Hal ini didukung oleh hasil wawancara yang dilakukan kepada responden, yang mengungkapkan bahwa mereka meras puas terhadap penggunaan SmartOne. Penggunaan SmartOne menjadi motivasi baru untuk bersaing dan meningkatkan kinerja. Secara positif keberadaan sistem informasi baru akan menjadi rangsangan (stimulus) dan tantangan bagi individu dalam organisasi untuk bekerja secara lebih baik, yang pada akhirnyaa berdampak pada kinerja organisasi.

\section{KESIMPULAN}

Evaluasi sistem informasi dan keberterimaan sistem oleh pengguna pada sistem informasi anggaran PT. PLN (Persero). Penggunaan sistem yang bersifat mandatori menjadi pertimbangan menguji keberterimaan oleh pengguna. Evaluasi terhadap SmartOne menggunakan model kesuksesan DeLone dan McLean (1992) dan mengukur penerimaan pengguna dengan menggunakan dua variabel dari TAM oleh Davis (1998). Berdasarkan hasil analisis yang dilakukan maka disimpulkan sebagai berikut: (1) Secara umum penerapan sistem informasi anggaran Smartone dapat dikatan sukses karena memberikan dampak yang positif dan signifikan terhadap individu. Hal ini dipengaruhi oleh kualitas sistem, kualitas informasi yang mudah untuk digunakan; (2) Hasil yang berbeda diperoleh pada kualias sistem dan kualitas informasi yang tidak berpengaruh terhadap kegunaan persepsi. Hal ini didasari oleh pengguna tidak merasakan kegunaan dari SmartOne dengan alasan beberapa fungsi sistem informasi anggaran dapat dilakukan oleh sistem yang sebelumnya digunakan. Dengan kata lain pengguna masih terbayang akan sistem lama yang mereka gunakan; (3) Penggunaan yang bersifat mandatori menjadi alasan pengguna tidak merasakan kegunaan dari sistem. Hal ini didukung oleh teori perilaku yang diwajibkan (mandatory behavior) penggunaan sistem yang bukan atas kemauannya sendiri tetapi karena memang tuntutan atau kewajiban dari pekerjaan pemanfaatan; (5) Sistem informasi anggaran Smartone adalah sistem dengan kualitas sistem dan kualitas infromasi yang relatif baik dan mudah untuk digunakan. Hal ini didukung, bahwa pengguna merasa puas atas kegunaan sistem dan sistem mudah untuk digunakan. Sehingga pengguna akan menggunakan sistem ini untuk terus menerus selama masih diwajibkan oleh perusahaan.

\section{DAFTAR PUSTAKA}

Adams, D.A., Nelson, R.R., and Todd, P.A. 1992. Perceived Usefulness, Ease of Use, and Usage of Information Technology: A Replication. MIS Quarterly. Vol. 16 (2), pp. 227-247).

Andiono. 2008. Evaluasi Implementasi Sistem Informasi Manajemen Kepegawaian (SIMPEG) di Badan Kepegawaian Daerah Kabupaten Banyumas. Tesis tidak terpublikasi. Purwokerto: Universitas Gadjah Mada.

Bailey, James. E. \& Pearson, Sammy. W. 1983. Development of A Tool for Measuring and Analysis Computer User Satisfaction. Management Science. Vol. 29, No. 5.

Baroudi, J.J., Olson, M.H., and Ives, B. 1986. An Empirical Study of the Impact of User Involvement on System Usage and Information Satisfaction. Management of Computing. March 1986 Volume 29 Number 3.

Bhattacherjee, A. 2001. Understanding Information System Continuance: An Expectation Confirmation Model. MIS Quarterly. Vol. 25, No. 3, 2001, pp. 351-370.

Bungin, Burhan,2 010. Penelitian Kualitatif : Komunikasi, Ekonomi, Kebijakan Publik dan Ilmu Sosia lainnya. Jakarta: Kencana Prenama Media Group.

Brown, I. and Jayakody, R. 2008. B2C eCommerce Success: a Test and Validation of a Revised Conceptual Model. The Electronic Journal Information Systems Evaluation Volume 11 Issue 3, pp. $167-184$.

Brown, I and Jayakody, R. 2009. B2C e- 
Commerce Success: A Test and Validation of a Revised Conceptual Model The Electronic Journal Information Systems Evaluation Volume 12 Issue 2, (pp129-148).

Chau, P. Y. K. 1996. An Empirical Assessment of a Modified Technology Acceptance Model. Journal of Management Information Systems. Vol. 12 (2). 185204.

Chervany, N.L., Dickson, G.W., and Kozar, K.A.. 1972. An Experimental Gaming Framework for Investigating the Influence of Management Information System on Decision Effectivenss. Managemen Information System. (71-12), Research Center, Minneapolis.

Chin, W.W., and Todd, P.A. 1995. On the use, usefulness, and ease of use of structural equation modeling in MIS research: A note of caution. MIS Quarterly (19:2), pp. 237-246.

Davis, F. D. 1989. Perceived Usefulness, Perceived Ease of Use, and User Acceptance of Information Technology. MIS Quarterly (13:3):319-399.

Davis, F.D. 1989. Perceived Usefulness, Perceived Ease of Use, and User Acceptance of Information Technology. MIS Quarterly, (13:3), p. 319-340.

DeLone, W.H. and McLean, E.R. 1992. Information systems success: The quest for the dependent variable. Informalion 5v.v/cm.v Research. 3. 1. 60-95.

DeLone, W. H., Dan E. R. McLean. 2003. The DeLone and McLean Model of Information System Succes: A Ten-Year Update. Journal of Management Information System. 19 N0.4:9-30.

Emery, J. C., 1971. Cost/Benefit Analysis of Information Systems. Society for Management Information Science. SMIS Workshop Report, No. 1 Chicago.

Ghozali, I. 2008. Structural Equation Modelling Metode Alternatif Dengan Partial Least Square. Purwokerto: Badan penerbit Universitas Diponegoro.

Horton, R. P., Buck, T., Waterson, P. E., \& Clegg, C. W. 2001. Explaining Intranet Use with the Technology Acceptance
Model. Journal of Information Technology, 16, 237-249.

Hair, J., Blake, W., Babin, B., and Tatham, R. 2006. Multivariate Data Analysis. Prentice Hall, New Jersey.

Hussein, R., dan Selamat. H., Abdul Karim, N.S. 2005. The Impact of Technological Factors on Iinformation Systems Success in The Electronic Govermen Context. The Second International Conference on Innovations in Information.

Igbaria, M. 1993. User Acceptance of Microcomputer Technology. International Journal of Management Science. 21 (1), 73-90.

Igbaria, M., Zinatelli, N., Cragg, P. and Cavaye, A. L. M. 1997. Personal Computing Acceptance Factors in Small Firms: A Structural Equation Modeling. MIS Quarterly, Vol. 21 (3), 279-305.

Iivari, J. 2005. An Empirical test of The DeLone and McLean Model of Information System Succes. The DATA BASE for Advance in Information System $(36: 2)$.

Jogiyanto, H.M. 2003. Metode Penelitian Bisnis: Salah Kaprah dan Pengalamanpengalaman. Penerbit Andi. Purwokerto.

Jogiyanto, H.M. 2007. Sistem Informasi Keperilakuan. Edisi Revisi. Penerbit Andi. Purwokerto.

Jogiyanto, H.M. 2008. Metodologi Penelitian Sistem Informasi. Penerbit Andi. Purwokerto.

Jogiyanto, H.M dan Abdillah, Willy. 2009. Konsep dan Aplikasi PLS (Partial Least Square). Untuk Penelitian Empiris. BPFE. Purwokerto.

Lee. Seul-Ki, and Yu. Jung-Ho. 2012. Success Model of Project Management Information System in Construction. Automation in Construction. 25. 82-93. Leavitt, H. J. 1965. Applied organizational change in industry: structural, technical and humanistic approaches, in March, J. G. (ed.), Handbook of

Organizations, $\quad 1144-1170$. Leavitt, H., \& Whisler, T. 1958. "Management in the 1980's." Harvard 
Business

Review, November-December, 1958, p.41-48. Lin, H. F. 2007. Measuring Online Learning System Succes: Appling The Update

DeLone and McLean Model. Cyber Psychology and Behaviour. (10:6):817- 820

Malone, T. W. 1997. Is "Empowerment" just a Fad? Control, Decision-making, and Information Technology. Sloan Management Review. 38 (2), 23-35

Mariana, Novita. 2006. Pengukur-Pengukur Kesuksesan Sistem Informasi Eksekutif. Jurnal Teknologi Informasi DINAMIK. Volume XI, No. 1, Januari 2006 : 30-37.

Mason, R.O. 1978. Measuring information output: A communication systems approach. Information and Management. 1.5. 219-234.

Mc Gill, T., Hobbs, V., and Klobas. J. 2003. User-developed applications and information systems success: a test of DeLone and McLean's model. Information Resources Management Journal. 16 (1), 24-45.

Norazah Mohd Suki, Azleen Ilias., Mohd Rushdan Yasoa', Rahida Abdul Rahman. A Study of Taxpayers' Intention in Using E-Filing System: A Case in Labuan F.T s. Computer and Information Science 1(2): 110-119 (2008).

Radityo, D., dan Zulaikha. 2007. Pengujian Model DeLone and McLean dalam pengembanganSistem Informasi Manajemen (Kajian sebuah kasus). Simposium Nasional Akuntansi X. Makassar: Universitas Hasanuddin.

Rai, A., Lang, S.S., dan Welker, R.B. 2002. Assessing the validity of IS success models: an empirical test and theoretical analysis. Information Systems Research 13(1), 5-69.

Rivard, S., dan Huff, S.L. 1985. An Empirical Study of Users as Application Developers. Information \& Management, Vol. 8 No. 2, February, pp. 89-102.

Roldan, J. L., dan A. Leal. 2003. A Validation Test of an Adaption of DeLone and McLean Model in the Spanish EIS Field. Idea Group Publising.
Saifudin, Santi Ayu Nindyowati, Anita Damajanti. 2013. Pengaruh Kualitas Infotmasi, Kemampuan Individual, dan Norma SubyektifF Terhadap Minat Mahasiswa Aakuntansi dalam Menggunakan Internet Sebagai Media Sumber Pustaka "Studi Empiris di UNDIP dan UNIKA Soegijapranata Semarang. Jurnal Dinamika Akuntansi Vol. 5. No. 1. (21-34)

Schelling, T. C. 1984. Self-command in practice, in policy, and in a theory of rational choice. American Economic Review, 74, 1-11

Seddon. P. B. 1997. A Respecification and Extension of The DeLone and McLean Model of IS Succes. Information System Research 8 No 3.

Seddon. P.B., dan M. Y. Kiew. 1994. A Partial Test and Development of the DeLone and McLean Model of IS Succes. Information System Research. 240253.

Seddon P.B., Graeser, R.V., and Wilcoks, L.P., 2002. Measuring organizational IS effectiveness: an overview and update of senior management perspectives. The DATA BASE for Advances in Information Systems 33(2), 11-28.

Venkatesh, V., dan Davis, F.D. 2000. A Theoretical Extention of The Technology Acceptance Model: Four Longitudinal Fields Studies. Managemen Science (46:2)., pp. 186-204.

Venkateshm V, Morris, M.G., Davis, G.B, and Davis, F.D. 2003 User acceptance of information technology: toward a unified view. MIS Quarterly 27(3), 425 $-478$.

Wang. Y, and Liao, Y. 2008. Assessing eGovernment systems success: A validation of the DeLone and McLean model of information systems success, Government Information Quarterly 25. pp. 717-733.

Zaied Abdel Nasser H. 2012. An Integrated Success Model for Evaluating Information System. Journal of Emerging Trends in Computing and Information Sciences VOL. 3, NO. 